\title{
Bio-efficacy of Spiromesifen 22.9 SC against Brinjal Mite, Tetranychus urticae Koch
}

\author{
H.C. Baladhiya, N.B. Patel*, V.I. Joshi and R.R. Acharya \\ Main Vegetable Research Station, \\ Anand Agricultural University, Anand - 388110 (Gujarat), India
}

*Corresponding author

\section{A B S T R A C T}

Keywords

Brinjal,

Spiromesifen, Mite, Tetranychus urticae

Article Info

Accepted:

10 June 2018

Available Online:

10 July 2018
To evaluate the effectiveness of different doses of spiromesifen 22.9 SC against brinjal mite, an experiment was conducted in the field of Main Vegetable Research Station, Anand Agricultural University, Anand (Gujarat) during the season of kharif-rabi, 2016-17. Two different doses of spiromesifen 22.9 SC of Meghmani Organics Ltd. with two doses of marketed product of spiromesifen @ 96 and $192 \mathrm{~g}$ a.i./ha were evaluated against brinjal mite. The tested product of Meghmani Organics Ltd. i.e. spiromesifen 22.9 SC @192 g a.i./ha found effective against mite and also produced higher brinjal fruits (29.54 tonnes/ha). All the acaricidal treatments under present study had no any significant impact on population of spiders.

\section{Introduction}

Brinjal (Solanum melongena Linnaeus) is considered as a "King of vegetables" originated from India, where a wide range of wild types and land races occur (Thompson and Kelly, 1957). India is the second largest producer of vegetables in the world next to China. The total area under brinjal in India is about 7.29 lakh hectares which produces 126.16 lakh tonnes brinjal fruits (Anonymous, 2018a). In Gujarat, the total area under brinjal is 0.74 lakh hectares with annual production of 14.86 lakh tonnes (Anonymous, 2018b).
Brinjal crop suffers severely due to the attack of various insect pests which reduces its yield and quality of fruits. Butani and Verma (1976) listed 36 insects, whereas Nayar et al., (1995) recorded 53 insects attacking on brinjal. Of which shoot and fruit borer, Leucinodes orbonalis Guenee; jassid, Amrasca biguttula biguttula (Ishida); whitefly, Bemisia tabaci Gennadius; aphid, Aphis gossypii Glover and non-insect pests like mites especially two spotted spider mite, Tetranychus urticae Koch are the main bottle necks in brinjal productivity. Among non-insect pests, mites are considerable notorious pests and gaining tremendous importance in recent years owing 
to their devastating nature and damage potential.

Basu and Pramanik (1968) ranked red spider mite as a major threat of brinjal crop next to shoot and fruit borer. Altogether, 23 species of mite pests have been reported infesting the crop from different parts of the world (Dhooria and Bindra, 1977). These mites inflict heavy damage to brinjal plant by sucking sap from under surface of leaves resulting in white speckles which coalesce and produced large patches. As the population increases, mites web profusely covering the entire foliage on all sides resulting in poor growth of the crop. In some cases, total failure of the crop has been reported. In case of severe infestation, adults form clusters at the tip of heavily infested plants, form ballooning threads and wait for wind to blow off the plant for dispersal. An average yield reduction of 13.64 and 31.09 per cent due to red spider mite, T. urticae at Bangalore and Varanasi, respectively was estimated (Anonymous, 1998).

\section{Materials and Methods}

Field experiment was conducted during kharif-rabi seasons of 2016-17 to assess the bio-efficacy of spiromesifen 22.9 SC in a Randomized Block Design (RBD) at Main Vegetable Research Station, Anand Agricultural University, Anand (Gujarat). For the purpose, brinjal variety Doli-5 was transplanted in 2nd week of August at a spacing of $90 \times 60 \mathrm{~cm}$ having plot size $4.5 \times$ $4.8 \mathrm{~m}$. All the standard agronomical package of practices recommended for the state except plant protection was followed for raising the crop. There were total five treatments replicated four times. The treatments included spiromesifen 22.9 SC @ $96 \mathrm{~g}$ a.i./ha (Tested Product), spiromesifen 22.9 SC @ 192 g a.i./ha (Tested Product), spiromesifen 22.9 SC @ 96 g a.i./ha (Marketed Product) and spiromesifen 22.9 SC @ 192 g (Marketed Product) along with untreated control. The first spray application was made at the initiation of pest and second was applied at 10 days interval. The spray volume was used @ 500 L/ha and it was adjusted according to the crop stage. The foliar spray application was done by using knapsack sprayer with hollow cone nozzle. Plot wise yield of brinjal fruits was recorded during each picking and finally converted into tonnes per ha.

For recording observations of mite, five plants were randomly selected and tagged in each net plot. The population of mite was recorded on $4.0 \mathrm{~cm} 2$ leaf area of three leaves selected randomly from top, middle and bottom canopy of the selected plants prior and after 3, 7 and 10 days of each spray. The data were statistically analyzed using square root transformation. Population of spiders was recorded before and after 7 and 10 days of each spray from five randomly selected plants. Fruit yield at each picking from each net plot area and finally converted into tonnes per ha.

\section{Results and Discussion}

\section{Bio-efficacy of spiromesifen 22.9 SC against brinjal mite}

Data on mite population recorded prior and 3, 7 and 10 days after both the sprays in different treatments during kharif-rabi, 2016-17 are given in Table 1. The data indicated that the mite population was uniformly distributed in all the experimental plots as it evident from the observations recorded before imposing of acaricidal spray.

The mite population recorded at 3 days after first spray (DAS) indicated that both the doses of tested product as well as marketed product of spiromesifen 22.9\% SC @ 96 and $192 \mathrm{~g}$ a.i./ha remained at par with each other. 
However, the lowest number of mite (0.99 mite/4 $\mathrm{cm} 2$ leaf) was observed in plots treated with spiromesifen $22.9 \%$ SC (Tested Product) @ $192 \mathrm{~g}$ a.i./ha followed by spiromesifen 22.9\% SC (Marketed Product) @ 192 g a.i./ha (1.22 mites/ $4 \mathrm{~cm}^{2}$ leaf). Observations recorded at 7 DAS indicated that among the different acaricides tested, spiromesifen $22.9 \%$ SC (Tested Product) @ 192 g a.i./ha recorded lowest (1.40 mites $/ 4 \mathrm{~cm}^{2}$ leaf) incidence of the pest whereas, the treatments of spiromesifen 22.9\% SC (Marketed Product) @ $192 \mathrm{~g}$ a.i./ha, spiromesifen 22.9\% SC (Tested Product) @ $96 \mathrm{~g}$ a.i./ha and spiromesifen $22.9 \% \mathrm{SC}$ (Marketed Product)@96 g a.i./ha stood next in effectiveness with relatively lower population of mites (1.72 to 2.16 mites $/ 4 \mathrm{~cm}^{2}$ leaf) over untreated control $\left(8.08\right.$ mites $/ 4 \mathrm{~cm}^{2}$ leaf). More or less same trend of effectiveness of spiromesifen $22.9 \%$ SC in controlling mite was also observed at $10 \mathrm{DAS}$.

Pooled data computed for the first spray indicated less number of mites (1.49 to 2.42 mites $/ 4 \mathrm{~cm}^{2}$ leaf) in the plots sprayed with both the doses of tested product as well as marketed product of spiromesifen $22.9 \%$ SC @ 96 and $192 \mathrm{~g}$ a.i./ha over untreated control (8.86 mites/ $4 \mathrm{~cm}^{2}$ leaf). However, the treatment of tested product of spiromesifen 22.9\% SC @ 192 g a.i./ha registered significantly lowest (1.49 mites/ $4 \mathrm{~cm}^{2}$ leaf) number of mites than rest of the treatments, except marketed product of spiromesifen 22.9\% SC @ $192 \mathrm{~g}$ a.i./ha $\left(1.75\right.$ mites/ 4 cm ${ }^{2}$ leaf) and tested product of spiromesifen $22.9 \%$ SC @ $96 \mathrm{~g}$ a.i./ha (2.29 mites/ $4 \mathrm{~cm}^{2}$ leaf) which remained at par with it.

The data on population of mite recorded at 3 days after second spray revealed minimum (0.64 mite $/ 4 \mathrm{~cm}^{2}$ leaf) numbers in plots treated with tested product of spiromesifen $22.9 \%$ SC @ $192 \mathrm{~g}$ a.i./ha and it was at par with both the doses of spiromesifen $22.9 \%$ SC marketed product@192 and $96 \mathrm{~g}$ a.i./ha (1.01 and 1.24 mite $/ 4 \mathrm{~cm}^{2}$ leaf) and tested product of spiromesifen 22.9\% SC @ $96 \mathrm{~g}$ a.i./ha (1.35 mite/4 $\mathrm{cm}^{2}$ leaf). On the other hand, the maximum ( 8.74 mite $/ 4 \mathrm{~cm}^{2}$ leaf) mites were observed in the untreated plots. Observations recorded at 7 DAS indicated that the tested product of spiromesifen 22.9\% SC @ $192 \mathrm{~g}$ a.i./ha found effective with lower (1.72 mites $/ 4 \mathrm{~cm}^{2}$ leaf) mite population than rest of the treatments, except marketed product of spiromesifen 22.9\% SC @ 912 and $96 \mathrm{~g}$ a.i./ha (1.75 and 2.19 mites $/ 4 \mathrm{~cm}^{2}$ leaf) and tested product of spiromesifen 22.9\% SC @ $96 \mathrm{~g}$ a.i./ha $\left(2.22 \mathrm{mites} / 4 \mathrm{~cm}^{2}\right.$ leaf). More or less same trend of effectiveness of spiromesifen $22.9 \%$ SC tested as well as marketed product @ 96 and $192 \mathrm{~g}$ a.i./ha in controlling mite was also found at 10 DAS.

Pooled data computed for the second spray indicated significantly less number of mites (1.35 to 1.75 mites $/ 4 \mathrm{~cm}^{2}$ leaf) in the plots sprayed with spiromesifen 22.9\% SC @ $192 \mathrm{~g}$ a.i./ha tested as well as marketed product. The plots treated with $96 \mathrm{~g}$ a.i./ha of spiromesifen 22.9\% SC marketed product stood next with significantly less $\left(2.06 \mathrm{mites} / 4 \mathrm{~cm}^{2}\right.$ leaf number of mites than untreated control, however, it was at par with tested product of spiromesifen 22.9\% SC @ 96 g a.i./ha (2.12 mites $/ 4 \mathrm{~cm}^{2}$ leaf).

Pooled over periods and sprays data computed for both the sprays indicated that all the acaricidal treatments proved significantly effective when compared with control after 3 , 7 and 10 days of spray as well as in pooled. Overall results indicated that spiromesifen 22.9\% SC (Tested Product) @ 192 g a.i./ha $\left(1.40 / 4 \mathrm{~cm}^{2}\right.$ leaf) and spiromesifen $22.9 \% \mathrm{SC}$ (Marketed Product) @ 192 g a.i./ha (1.75/4 $\mathrm{cm}^{2}$ leaf) proved significantly more effective than rest of the treatments. Spiromesifen 22.9\% SC (Tested Product) @ 96 g a.i./ha $\left(2.19 / 4 \mathrm{~cm}^{2}\right.$ leaf) and spiromesifen $22.9 \% \mathrm{SC}$ (Marketed Product)@ $96 \mathrm{~g}$ a.i./ha $\left(2.22 / 4 \mathrm{~cm}^{2}\right.$ 
leaf) found equally effective against mite. All the acaricidal treatments found significantly superior over control ( 8.92 mites $/ 4 \mathrm{~cm}^{2}$ leaf).

\section{Natural enemies}

The population of natural enemies prevailing in brinjal crop was very low. However, the population of spiders was observed during the study period. The data recorded for these natural enemies are presented in Table 2. There was no significant effect of any of the acaricidal treatments after 7 and 10 days of application as the data are non-significant. Data clearly indicated that all the acaricidal treatments under present study had no any significant impact on population of spiders.

Table.1 Effectiveness of spiromesifen 22.9 SC evaluated against two different doses against brinjal mite

\begin{tabular}{|c|c|c|c|c|c|c|c|c|c|c|}
\hline \multirow[t]{3}{*}{ Treatments } & \multicolumn{10}{|c|}{ Number of mites/ leaf $\left(4 \mathrm{~cm}^{2}\right)$} \\
\hline & \multirow{2}{*}{$\begin{array}{l}\text { Before } \\
\text { spray }\end{array}$} & \multicolumn{3}{|c|}{$1^{\text {st }}$ spray (DAS) } & \multirow[t]{2}{*}{ Pooled } & \multicolumn{3}{|c|}{$2^{\text {nd }}$ spray (DAS) } & \multirow[t]{2}{*}{ Pooled } & \multirow{2}{*}{$\begin{array}{l}\text { Pooled over } \\
\text { periods and } \\
\text { sprays }\end{array}$} \\
\hline & & 3 & 7 & 10 & & 3 & 7 & 10 & & \\
\hline $\begin{array}{l}\text { Spiromesifen 22.9 SC @ } 96 \text { g } \\
\text { a.i./ha (Tested Product) }\end{array}$ & $\begin{array}{c}2.42 \\
(5.36)\end{array}$ & $\begin{array}{l}1.36 \mathrm{a} \\
(1.35)\end{array}$ & $\begin{array}{l}1.61 \mathrm{a} \\
(2.09)\end{array}$ & $\begin{array}{l}2.03 \mathrm{a} \\
(3.62)\end{array}$ & $\begin{array}{l}1.67 \mathrm{ab} \\
(2.29)\end{array}$ & $\begin{array}{r}1.36 \mathrm{a} \\
(1.35)\end{array}$ & $\begin{array}{l}1.65 \mathrm{a} \\
(2.22)\end{array}$ & $\begin{array}{l}1.84 \mathrm{a} \\
(2.89)\end{array}$ & $\begin{array}{l}1.62 \mathrm{~b} \\
(2.12)\end{array}$ & $\begin{array}{l}\text { 1.64b } \\
(2.19)\end{array}$ \\
\hline $\begin{array}{l}\text { Spiromesifen 22.9 SC @ } 192 \mathrm{~g} \\
\text { a.i./ha (TestedProduct) }\end{array}$ & $\begin{array}{c}2.23 \\
(4.47)\end{array}$ & $\begin{array}{l}1.22 \mathrm{a} \\
(0.99)\end{array}$ & $\begin{array}{l}1.38 \mathrm{a} \\
(1.40)\end{array}$ & $\begin{array}{l}1.61 \mathrm{a} \\
(2.09)\end{array}$ & $\begin{array}{r}1.41 \mathrm{a} \\
(1.49)\end{array}$ & $\begin{array}{r}1.07 \mathrm{a} \\
(0.64)\end{array}$ & $\begin{array}{r}1.49 \mathrm{a} \\
(1.72)\end{array}$ & $\begin{array}{l}1.53 \mathrm{a} \\
(1.84)\end{array}$ & $\begin{array}{l}1.36 \mathrm{a} \\
(1.35)\end{array}$ & $\begin{array}{l}1.38 a \\
(1.40)\end{array}$ \\
\hline $\begin{array}{l}\text { Spiromesifen 22.9 SC @ } 96 \text { g } \\
\text { a.i./ha (Marketed Product) }\end{array}$ & $\begin{array}{c}2.34 \\
(4.98)\end{array}$ & $\begin{array}{l}1.46 \mathrm{a} \\
(1.63)\end{array}$ & $\begin{array}{l}1.63 \mathrm{a} \\
(2.16)\end{array}$ & $\begin{array}{l}2.04 \mathrm{a} \\
(3.66)\end{array}$ & $\begin{array}{l}1.71 \mathrm{~b} \\
(2.42)\end{array}$ & $\begin{array}{l}1.32 \mathrm{a} \\
(1.24)\end{array}$ & $\begin{array}{l}1.64 \mathrm{a} \\
(2.19)\end{array}$ & $\begin{array}{l}1.84 \mathrm{a} \\
(2.89)\end{array}$ & $\begin{array}{l}1.60 \mathrm{ab} \\
(2.06)\end{array}$ & $\begin{array}{l}1.65 b \\
(2.22)\end{array}$ \\
\hline $\begin{array}{l}\text { Spiromesifen 22.9 SC @ } 192 \mathrm{~g} \\
\text { a.i./ha (Marketed Product) }\end{array}$ & $\begin{array}{c}2.67 \\
(6.63)\end{array}$ & $\begin{array}{l}1.31 \mathrm{a} \\
(1.22)\end{array}$ & $\begin{array}{l}1.49 \mathrm{a} \\
(1.72)\end{array}$ & $\begin{array}{l}1.71 \mathrm{a} \\
(2.42)\end{array}$ & $\begin{array}{l}1.50 \mathrm{ab} \\
(1.75)\end{array}$ & $\begin{array}{r}1.23 \mathrm{a} \\
(1.01)\end{array}$ & $\begin{array}{l}1.50 \mathrm{a} \\
(1.75)\end{array}$ & $\begin{array}{l}1.78 \mathrm{a} \\
(2.67)\end{array}$ & $\begin{array}{l}1.50 \mathrm{ab} \\
(1.75)\end{array}$ & $\begin{array}{c}\text { 1.50ab } \\
(1.75)\end{array}$ \\
\hline Untreated control & $\begin{array}{c}2.65 \\
(6.52)\end{array}$ & $\begin{array}{l}3.11 b \\
(9.17)\end{array}$ & $\begin{array}{l}2.93 b \\
(8.08)\end{array}$ & $\begin{array}{l}3.14 b \\
(9.36)\end{array}$ & $\begin{array}{l}3.06 c \\
(8.86)\end{array}$ & $\begin{array}{c}3.04 b \\
(8.74)\end{array}$ & $\begin{array}{c}3.25 b \\
(10.06)\end{array}$ & $\begin{array}{c}2.95 b \\
(8.20)\end{array}$ & $\begin{array}{l}3.08 \mathrm{c} \\
(8.99)\end{array}$ & $\begin{array}{l}3.07 c \\
(8.92)\end{array}$ \\
\hline S.Em. \pm & 0.33 & 0.17 & 0.14 & 0.20 & 0.10 & 0.12 & 0.14 & 0.18 & 0.09 & 0.08 \\
\hline $\mathbf{P}$ & - & - & - & - & 0.08 & - & - & - & 0.07 & 0.05 \\
\hline $\mathbf{S}$ & - & - & - & - & - & - & - & - & - & 0.04 \\
\hline $\mathbf{T} \times \mathbf{P}$ & - & - & - & - & 0.17 & - & - & - & 0.15 & 0.09 \\
\hline $\mathbf{T} \times \mathbf{S}$ & - & - & - & - & - & - & - & - & - & 0.07 \\
\hline $\mathbf{S} \times \mathbf{P}$ & - & - & - & - & - & - & - & - & - & 0.11 \\
\hline $\mathbf{T} \times \mathbf{S} \times \mathbf{P}$ & - & - & - & - & - & - & - & - & - & 0.15 \\
\hline C. D. at $5 \% \mathrm{~T}$ & NS & 0.52 & 0.44 & 0.61 & 0.27 & 0.38 & 0.43 & 0.56 & 0.25 & 0.23 \\
\hline $\mathbf{P}$ & - & - & - & - & - & - & - & - & - & 0.13 \\
\hline $\mathbf{S}$ & - & - & - & - & - & - & - & - & - & NS \\
\hline $\mathbf{T} \times \mathbf{P}$ & - & - & - & - & NS & - & - & - & NS & NS \\
\hline $\mathbf{T} \times S$ & - & - & - & - & - & - & - & - & - & NS \\
\hline $\mathbf{S} \times \mathbf{P}$ & - & - & - & - & - & - & - & - & - & NS \\
\hline $\mathbf{T} \times \mathbf{S} \times \mathbf{P}$ & - & - & - & - & - & - & - & - & - & NS \\
\hline C. V. (\%) & 26.49 & 19.75 & 15.88 & 18.76 & 18.28 & 15.16 & 14.70 & 18.39 & 16.41 & 16.09 \\
\hline
\end{tabular}


Table.2 Effectiveness of spiromesifen 22.9 SC on predatory spiders in brinjal

\begin{tabular}{|c|c|c|c|c|c|c|c|c|}
\hline \multirow[t]{3}{*}{ Treatments } & \multicolumn{8}{|c|}{ Number of predatory spiders/ plant } \\
\hline & \multirow[t]{2}{*}{$\begin{array}{l}\text { Before } \\
\text { spray }\end{array}$} & \multicolumn{2}{|c|}{$\begin{array}{l}1^{\text {st }} \text { spray } \\
(\text { DAS })\end{array}$} & \multirow[t]{2}{*}{ Pooled } & \multicolumn{2}{|c|}{$\begin{array}{c}2^{\text {nd }} \text { spray } \\
\text { (DAS) }\end{array}$} & \multirow[t]{2}{*}{ Pooled } & \multirow{2}{*}{$\begin{array}{l}\text { Pooled over } \\
\text { periods and } \\
\text { sprays }\end{array}$} \\
\hline & & 7 & 10 & & 7 & 10 & & \\
\hline $\begin{array}{l}\text { Spiromesifen 22.9 SC @ } 96 \mathrm{~g} \\
\text { a.i./ha (TestedProduct) }\end{array}$ & $\begin{array}{c}0.96 \\
(0.42)\end{array}$ & $\begin{array}{c}0.88 \\
(0.27)\end{array}$ & $\begin{array}{c}0.91 \\
(0.33)\end{array}$ & $\begin{array}{c}0.90 \\
(0.31)\end{array}$ & $\begin{array}{c}0.97 \\
(0.44)\end{array}$ & $\begin{array}{c}0.88 \\
(0.27)\end{array}$ & $\begin{array}{c}0.92 \\
(0.35)\end{array}$ & $\begin{array}{c}\mathbf{0 . 9 1} \\
(\mathbf{0 . 3 3})\end{array}$ \\
\hline $\begin{array}{l}\text { Spiromesifen 22.9 SC @ } 192 \text { g } \\
\text { a.i./ha (TestedProduct) }\end{array}$ & $\begin{array}{c}0.96 \\
(0.42)\end{array}$ & $\begin{array}{c}0.98 \\
(0.46)\end{array}$ & $\begin{array}{c}0.86 \\
(0.24)\end{array}$ & $\begin{array}{c}0.92 \\
(0.35)\end{array}$ & $\begin{array}{c}0.94 \\
(0.38)\end{array}$ & $\begin{array}{c}0.90 \\
(0.31)\end{array}$ & $\begin{array}{c}0.92 \\
(0.35)\end{array}$ & $\begin{array}{c}0.92 \\
(0.35)\end{array}$ \\
\hline $\begin{array}{l}\text { Spiromesifen 22.9 SC @ } 96 \text { g } \\
\text { a.i./ha (Marketed Product) }\end{array}$ & $\begin{array}{c}0.93 \\
(0.36)\end{array}$ & $\begin{array}{c}0.98 \\
(0.46)\end{array}$ & $\begin{array}{c}0.92 \\
(0.35)\end{array}$ & $\begin{array}{c}0.95 \\
(0.40)\end{array}$ & $\begin{array}{c}0.94 \\
(0.38)\end{array}$ & $\begin{array}{c}0.93 \\
(0.36)\end{array}$ & $\begin{array}{c}0.93 \\
(0.36)\end{array}$ & $\begin{array}{c}0.94 \\
(0.38)\end{array}$ \\
\hline $\begin{array}{l}\text { Spiromesifen 22.9 SC @ } 192 \text { g } \\
\text { a.i./ha (Marketed Product) }\end{array}$ & $\begin{array}{c}0.96 \\
(0.42)\end{array}$ & $\begin{array}{c}1.02 \\
(0.54)\end{array}$ & $\begin{array}{c}0.91 \\
(0.33)\end{array}$ & $\begin{array}{c}0.96 \\
(0.42)\end{array}$ & $\begin{array}{c}0.94 \\
(0.38)\end{array}$ & $\begin{array}{c}0.95 \\
(0.40)\end{array}$ & $\begin{array}{c}0.95 \\
(0.40)\end{array}$ & $\begin{array}{c}0.95 \\
(0.40)\end{array}$ \\
\hline Untreated control & $\begin{array}{c}1.02 \\
(0.54)\end{array}$ & $\begin{array}{c}0.96 \\
(0.42)\end{array}$ & $\begin{array}{c}1.01 \\
(0.52)\end{array}$ & $\begin{array}{c}0.98 \\
(0.46)\end{array}$ & $\begin{array}{c}0.90 \\
(0.31)\end{array}$ & $\begin{array}{c}0.92 \\
(0.35)\end{array}$ & $\begin{array}{c}0.91 \\
(0.35)\end{array}$ & $\begin{array}{c}0.95 \\
(0.40)\end{array}$ \\
\hline S.Em. \pm & 0.05 & 0.05 & 0.04 & 0.04 & 0.05 & 0.06 & 0.04 & 0.03 \\
\hline $\mathbf{P}$ & - & - & - & 0.02 & - & - & 0.03 & 0.02 \\
\hline $\mathbf{S}$ & - & - & - & - & - & - & - & 0.02 \\
\hline $\mathbf{T} \times \mathbf{P}$ & - & - & - & 0.05 & - & - & 0.05 & 0.03 \\
\hline $\mathbf{T} \times S$ & - & - & - & - & - & - & - & 0.02 \\
\hline$S \times P$ & - & - & - & - & - & - & - & 0.03 \\
\hline$T \times S \times P$ & - & - & - & - & - & - & - & 0.05 \\
\hline C. D. at 5\% & NS & NS & NS & NS & NS & NS & NS & NS \\
\hline $\mathbf{P}$ & - & - & - & - & - & - & - & NS \\
\hline $\mathbf{S}$ & - & - & - & - & - & - & - & NS \\
\hline $\mathbf{T} \times \mathbf{P}$ & - & - & - & NS & - & - & NS & NS \\
\hline $\mathbf{T} \times S$ & - & - & - & - & - & - & - & NS \\
\hline $\mathbf{S} \times \mathbf{P}$ & - & - & - & - & - & - & - & NS \\
\hline $\mathbf{T} \times S \times P$ & - & - & - & - & - & - & - & NS \\
\hline C. V. (\%) & 10.02 & 10.47 & 9.75 & 10.13 & 10.81 & 12.39 & 11.61 & 10.18 \\
\hline
\end{tabular}

Table.3 Effect of spiromesifen 22.9 SC on yield of brinjal fruits

\begin{tabular}{|l|c|}
\hline \multicolumn{1}{|c|}{ Treatments } & $\begin{array}{c}\text { Yield } \\
\text { (Tonnes/ha) }\end{array}$ \\
\hline Spiromesifen 22.9 SC @ 96 g a.i./ha (Tested Product) & $28.73 \mathrm{a}$ \\
\hline Spiromesifen 22.9 SC @ 192 g a.i./ha (Tested Product) & $29.54 \mathrm{a}$ \\
\hline Spiromesifen 22.9 SC @ 96 g a.i./ha (Marketed Product) & $29.21 \mathrm{a}$ \\
\hline Spiromesifen 22.9 SC @ 192 g a.i./ha (Marketed Product) & $32.03 \mathrm{a}$ \\
\hline Untreated Control & $7.24 \mathrm{~b}$ \\
\hline S. Em. \pm & 1.59 \\
\hline C. D. at 5\% & 4.91 \\
\hline C.V. $(\%)$ & 12.56 \\
\hline
\end{tabular}




\section{Fruit yield}

The data (Table 3) on yield of brinjal fruits recorded in different treatments indicated that the highest (32.03 tonnes/ha) yield was harvested from the plots sprayed with marketed product of spiromesifen $22.9 \%$ SC @ $192 \mathrm{~g}$ a.i./ha, however, it was at par with rest of the acaricidal treatments i.e. tested product of spiromesifen 22.9\% SC @ $192 \mathrm{~g}$ a.i./ha (29.54 tonnes/ha), marketed product of spiromesifen 22.9\% SC @ $96 \mathrm{~g}$ a.i./ha (29.21 tonnes/ha) and tested product of spiromesifen 22.9\% SC @ 96 g a.i./ha (28.73 tonnes/ha). However, the lowest yield was recorded in untreated plots (7.24 tonnes/ha) which was significantly differed from rest of the acaricidal treatments.

The present study is in conformity with the finding of Sekh et al., (2007), spiromesifen 240 SC (Oberon) @ $0.7 \mathrm{ml} / 1$ registered an excellent control of two spotted spider mite on brinjal, coupled with significant increase in fruit yield. Fanigliulo et al., (2010) observed that spiromesifen @ 45 and $60 \mathrm{~g} / \mathrm{hl}$ both were very effective in control of mite on Capsicum annuum L. as well as there were no phenomena of phytotoxicity nor on leaves nor on flowers and fruits in none of the treatments and highlighted the lack of harmful effects on predators and on parasitoids of insects and mites. Kavya et al., (2015) who reported that spiromesifen reduced the overall mite population more significantly along with significant increase in yield and it was very safe to important natural enemies in brinjal crop. Pathipati et al., (2017) recorded less population of mite in the treatment of spiromesifen 22.9 SL. As per the report of Varghese and Mathew (2013), spiromesifen @ $100 \mathrm{~g}$ a.i./ha found effective in reducing chilli mite population. It was found the safest insecticide against natural enemies viz., predatory mites, coccinellid beetles and spiders.
In conclusion, the tested product spiromesifen 22.9 SC @ 192 g a.i./ha found most effective against mite, Tetranychus urticae Koch in brinjal and it was at par with marketed product of spiromesifen 22.9 SC @ $192 \mathrm{~g}$ a.i./ha. This treatment also produced higher brinjal fruits. Similarly, spiromesifen 22.9 SC @ $96 \mathrm{~g}$ a.i./ha, a tested product of M/s. Meghmani Organics Limited, Ahmedabad found as effective as spiromesifen 22.9 SC @ $96 \mathrm{~g}$ a.i./ha, a marketed product.

Both the products (tested and marketed) evaluated in present study registered more or less equal number of spiders. There was no significant difference in number of spiders recorded in different treatments including untreated check. It indicated the safety property of the test product to beneficial arthropods. The tested product spiromesifen 22.9 SC @ 96 and $192 \mathrm{~g}$ a.i./ha found safer to natural enemies. In case of fruit yield, maximum yield of brinjal fruits was registered from the plots treated with spiromesifen 22.9 SC @ 192 g a.i./ha followed by lower dose of spiromesifen 22.9 SC@ 96 g a.i./ha.

\section{Acknowledgement}

The authors are thankful to Meghmani Organics Limited, Ahmedabad (Gujarat) for the financial assistance given for testing of its product spiromesifen 22.9 SC.

\section{References}

Anonymous (1998). Progress Report for 1996-98. All India Coordinated Research Project on Agricultural Acarology, UAS, GKVK, Bangalore, pp.136.

Anonymous (2018a). Area and Production of Horticulture Crops - All India 201617(Final). http://agricoop.gov.in/sites/default/file 
s/2017-

18\%281st\%20Adv.\%20Est\%29.pdf

Anonymous, (2018b). District wise estimated area $\&$ production of vegetable crops year 2016-17 of Gujarat. https://doh.gujarat.gov.in/Images/direc torofhorticulture/pdf/ statistics/AreaProduction-2016-17-guj.pdf.

Basu, A. C. and Pramanik, L. M. (1968). Acaricidal tests of nine pesticides against two spotted spider mite, a serious pest of brinjal in West Bengal. J. Econ. Entomol., 61: 768-770.

Butani, D.K. and Verma, S. (1976). Pest of vegetable and their control-Brinjal. Pesticides, 10(2): 32-38.

Dhooria, M. S. and Bindra, O. S. (1977). Incidence of Tetranychus neocaledonicus Andre and Tetranychus cinnabarinus (Boisd.) on different varieties of brinjal. J. Res. Punjab Agril. Univ., 14: 63 - 65.

Fanigliulo, A., Massa, C. G., Ielpo, L., Pacella, R. and Crescenzi, A. (2010). Evaluation of the efficacy of oberon (Spiromesifen), to contain infestations of mites and whiteflies on Capsicum annuum L. Communications in Agricultural and Applied Biological Sciences. 75(3):341-344.

Kavya, M. K., Srinivasa, N., Vidyashree, A. S. and Ravi, G. B. (2015). Bioefficacy of newer acaricides against two spotted spider mite, Tetranychus urticae and phytoseiid predator, Neoseiulus longispinosus on brinjal under field condition. Plant Archives, 15(1): 493-497.

Nayar, K. K., Anantha Krishnan, T. N. and David, B. V. (1995). General and Applied Entomology. 11th Edn. Tata McGraw- Hill pub. Co. Ltd. 4/12, New Delhi-110002, pp. 557.

Pathipati, V. L., Singh, T. V. K., Vemuri, S. B., Reddy, R. V. S. K. and Bharathi, N. B. (2017). Bio-efficacy and dissipation studies of spiromesifen against mite, Polyphagotarsonemus latus banks on capsicum under field conditions. Asian Journal of Biological Sciences, 12(2): 202-208.

Sekh, K., Nair, N., Bag, V. and Somchoudhury, A.K. (2007). Bioefficacy of spiromesifen 240 SC (Oberon) against red spider mite of brinjal and effect on its natural enemies. Pestology, 31: 25-28.

Thompson, C. H. and Kelly, C. W. (1957). Vegetable crops. Mc. Graw Hill book Co. Inc. USA, pp. 501.

Varghese, T.S. and Mathew, T.B. (2013). Bio-efficacy and safety evaluation of newer insecticides and acaricides against chilli thrips and mites. J. Tropical Agric., 51(1- 2): 111-115.

\section{How to cite this article:}

Baladhiya, H.C., N.B. Patel, V.I. Joshi and Acharya, R.R. 2018. Bio-efficacy of Spiromesifen 22.9 SC against Brinjal Mite, Tetranychus urticae Koch. Int.J.Curr.Microbiol.App.Sci. 7(07): 1650-1656. doi: https://doi.org/10.20546/ijcmas.2018.707.193 